\title{
Private Colleges in China: their Core Competences and Future Development
}

\author{
Duan Yong and Zhao Xiaokang \\ School of Business Administration, Donghua University \\ duanyongdh@163.com
}

\begin{abstract}
Private colleges in China have the dual natures of public products and profit-driven entities. Since the late 1970s, private higher education began, the positioning and development model are in the process of constantly updated and improved. In this paper, I try to describe the current situation of the development through the development scale, development model and development characteristics of the private higher education in China, analyze the internal and external influencing factors in the development process of private higher education emphatically. In the end, propose the countermeasures and suggestions for the future development of private colleges. Conclusions: Private colleges should design strategy under the guidance of national policy, choose the future development mode actively; Strive for government support and subsidies actively; Guide the whole society's investment in private higher education actively; Improve the ability and level of teaching staff; Pay special attention to students' recruitment, cultivating and employment, to improve students' quality.
\end{abstract}

Keywords: Private College, Development Status, Influence factors, Countermeasures

\section{Introduction}

\subsection{The Emerging of Private Colleges in China}

After the founding of new China, the private schools were once prohibited. Thanks to the ending of the Cultural Revolution, China's private higher education entered into the recovery period of development. In 1978, Hunan Yat-Sen College of Education which is the first private college in China established[1].After the Third Plenary Session of the Eleventh, under the background that the higher education total reliance on the government investment is difficult to meet the demand of social development, private colleges began the development process. According to the survey of Chinese Private Higher Education Committee in 1988, more than 40 private colleges were founded in 1984-1988 [2].

Deng Xiaoping' s southern tour and the party's fourteenth congress promoted the development of private colleges greatly. But until 1993, the state education commission issued the Interim Provisions on Private Colleges, the concept of "private colleges" had a clear explanation. In 1993, China Education Mission and Development Outline put forward the guideline about running of schools by non-governmental social forces "Actively encourage, strongly support, correct guidance and strengthen management".

In 1997, the State Council promulgated Regulations on the Social Forces of Running a School, which is China's first regulation for non-government funded education. It contained the basic principles of development of private education, teaching and administrative management, property and financial management, the government guarantee and support, etc., 1990s became the golden age of private colleges' rapid development.

In the 21st century, China's private colleges have the characteristics such as increasing categories and levels, funds source is single, operation mechanism is marketing, etc. In 
December 2002, the state issued the Private Education Promotion Law of The People's Republic of China, it has the specific provision: "Private education belongs to public welfare undertakings, also a component part of socialist education, establishing the equal legal status between private education and public education. The National Medium and Long-term Education Reform and Development Plan Outline (2010-2020) pointed out explicitly: "private education is one of the important growth points of national education and important force to promote the reform of education.

After more than 30 years of exploration and development, private colleges have become an important part of China's higher education; strongly promote the development of China's higher education.

\subsection{Literature Review}

The first research on private colleges appeared in the 1980s, with the passage of time, the related research is more and more popular. In the CNKI database, use "private colleges" as the title searching keywords, from 1987 to 1998, the annual number of research literature is less than 6 , the number increased to 100 after the year 2000 , the annual growth rate is about $50 \%$, the annual number of research literature in recent three years are over 1,000 .

Through the analysis of the literature, the research content mainly includes the following aspects : 1.The operation and management system of the private colleges; 2.Construction of teaching staff and human resource management; 3.Teaching scientific research and personnel training; 4.The ideological and political education, counselors, student management and employment; 5.financial management, profit problems; 6.Brand construction; 7. Sustainable development and core competitiveness; 8.Policy and government support; 9. The influence factors of development of private colleges, countermeasures and development strategy research.

For private colleges development situation and the countermeasure research mainly based on the following viewpoints: Research on current situation of the development of private colleges in certain province, city etc. and put forward countermeasures; Status and countermeasures of certain problems in private colleges, such as the ideological and political quality [5], student management [6], scientific research [7] etc. Problem angle, analyze the problems of private colleges and give advice. [8]

The existing research has three deficiencies: Firstly, research and evaluation on the development environment and present situation is insufficient, countermeasure and strategy research should base on the current situation and full analysis; Secondly, from theory to theory, many research results ignored the practical problems in private colleges, the countermeasures are not combined with practice closely enough; Thirdly, few studies mentioned the development history of private colleges. This paper expects to make some improvement in these three aspects.

\section{Private Higher Education's Development in China}

\subsection{Current Private Higher Education Scenario in China}

According to 2012 statistics bulletin of the national education[9] released in August 2013 by Ministry of Education, The number of colleges and universities in China is 2442 (including 303 independent colleges); The number of private colleges is 707(including 303 independent colleges), 9 more than one year before, $29 \%$ of the total number of national colleges and universities; Recruit 1.6028 million students, 65.5 thousand more than the previous year; the number of students at school is 5.3318 million, 281.1 thousand more than the previous year. Among them, there are 155 graduate students, 3.4123 million undergraduate students, and 1.9194 million college students; the number of self- 
study students, preppy, training students is 220.4 thousand. There are 823 private noncurricula higher education institutions, 828.2 registered students.

Table 2-1. The Scale Statistics of Chinese Private Higher Education (20052011) Data source: Ministry of Education

\begin{tabular}{|l|l|l|l|l|}
\hline & $\begin{array}{l}\text { private } \\
\text { colleges }\end{array}$ & $\begin{array}{l}\text { students at } \\
\text { school(Million) }\end{array}$ & $\begin{array}{l}\text { Undergraduate } \\
\text { students(Million) }\end{array}$ & $\begin{array}{l}\text { Junior college } \\
\text { students(Million) }\end{array}$ \\
\hline 2005 & 547 & 2.1263 & 1.005 & 1.1213 \\
\hline 2006 & 596 & 2.8049 & 1.3899 & 1.415 \\
\hline 2007 & 615 & 3.4969 & 1.868 & 1.6288 \\
\hline 2008 & 640 & 4.013 & 2.233 & 1.78 \\
\hline 2009 & 658 & 4.4614 & 2.5248 & 1.9366 \\
\hline 2010 & 676 & 4.7668 & 2.8099 & 1.957 \\
\hline 2011 & 698 & 5.0507 & 3.1182 & 1.9325 \\
\hline
\end{tabular}

Since the 1980s, the number of private colleges is down bearing within up bearing. The total number of Schools increased year by year, especially private colleges has always been on the rise; But the overall number of private higher education institutions rise in some years, decline in some years; Enrollment number of students was increasing year by year. China's private higher education has become an important part of higher education system, its development eased the social demand for higher education to a certain extent, and it also cultivated a large number of talents for the country's construction and development.

\subsection{The Development Pattern Analysis of Private Higher Education}

Since 2010, some provinces and cities carried on the classified management reform trial of the private colleges, let the colleges choose non-profit or profitability patterns. [10] According to profit making or not, the government divided all private colleges into two types: non-profit and profitability patterns, it is the so-called "dichotomy". This is a common classification method of foreign colleges and universities, non-profit schools are usually donated, few in our country. In Shanghai, there are more than 20 private colleges, only Shanda College was developed by endowing, the other colleges are invested [11]. Analysis on the present development situation of private colleges in our country, only a few colleges would choose the non-profit pattern, most of the private college founders are holding the profitable purpose; the possibility of choosing profitability pattern is less likely, because if they chose the profitability pattern, government would adopt the similar management policy as to the private enterprise, the profit space will be small. So quite a number of private colleges would choose watching, or eventually withdraw.

Professor Pan Maoyuan, a famous higher education scholar, wrote papers to issue viewpoints about the development patterns of private higher education. He thought it's not practical to divide the private colleges into two categories at present development stage, it is difficult to be accepted by most of the operators, also can't cover the types of private colleges in our country, which goes against to the sustainable development of private colleges. Professor Pan proposed a "Third way" of the development of the private colleges, combining the public welfare of education with profitable of investment.

Similar to the views of Professor Pan, based on the analysis of private colleges' marketization development characteristics and challenges in China, Zha Minghui put forward the future development pattern of Chinese private higher education clearly - the Social Enterprise Development Pattern [12]. The operators of private colleges could take means of enterprise, follow the welfare principle, to provide higher education. The concept of "Social Enterprise" refers to using market and non-market resources; let the 
low skilled workers back to work. Later, the meaning of social enterprise expanded to those who use commercial means to pursue social purposes [13].

Private colleges' active choice on development strategy and pattern under the national policy guidance is important for their far-reaching development. National policy lag behind the development of the theory and practice, on one hand, private colleges should grasp the trend, use the forward-looking vision to develop strategy, choose the development pattern, grow as much as possible under the national policy guidance; on the other hand, private colleges should call for the adjustment of national policy, fight for more support and space to the development of private higher education.

\subsection{Analysis of Development Characteristics of Private Higher Education}

Enrollment expansion of colleges and universities in China started from 1999, higher education in China transferred from elite education to popular education. The number of private higher education students at school accounts for about $10 \%$ of the whole higher education scale [14].

\subsection{The Amount of Private Colleges Are Small}

The admissions environment for private colleges is difficult, private colleges not only competing with the independent colleges whose background is public colleges, but also with self-study classes run by public colleges. In 1999, the scale of higher education in China is 7.42 million; in 2003, the scale is 19 million, increased 1.56 times. The scale of private higher education is 1.488 million in 1999, in 2003, the students number is 1.814 million, an increase of $21.9 \%$ [15]. So, the development speed of private higher education is far lagging behind the public higher education, the development level is lag behind the overall level of higher education.

\subsection{The Structures of Private Colleges Are Simple}

After 30 years of development and accumulation, the number of private colleges which have the degree education increased rapidly, especially for undergraduate education, The 2012 Statistics Bulletin of National Education issued by Ministry of Education showed that private colleges began to recruit graduate student, 155 students in total. Even so, the overall structure of private higher education in China is too simple, the number of colleges which could supply undergraduate education is still too few, skilled personnel training pattern is not innovative.

\subsection{Private Colleges are not Distributed Evenly Among Provinces and Regions}

The regional structure of private colleges has uneven distribution. As for the other types of private higher education institutions, mainly concentrated in provinces and cities such as Shanghai, Liaoning, Shandong, Beijing, Hebei, etc. As for the private colleges, most of them are mainly distributed in provinces such as Guangdong, Shandong, Jiangsu, Fujian, Shanxi, Shanghai, Hubei, etc. Provinces each has more than 15 colleges are Guangdong, Shandong, Jiangsu, Shanghai, Fujian, Shaanxi etc. [16].

\subsection{Private Colleges have Poor Social Reputation}

After 30 years of development, some of the private colleges in China have good social reputation, but affected by the factors such as traditional ideas, public recognition of "good colleges" are all public colleges. General public local colleges are better than the high quality private colleges in public's opinion. Generally speaking, parents would consider sending their kids to private colleges only in the situation that the kids could not enroll into the public colleges. The social reputation and status of the private colleges in public mind is obvious [17]. 


\section{The Influencing Factors of Private Higher Education Development}

At present, the problems in private higher education development in China are from two aspects: one is the external environment influence [18], the other one is the internal problems.

External environments Analysis

Inefficient supports from the governments and society

Private Education Promotion Law of the People's Republic of China made clear that "private education belongs to public welfare undertakings, is a component part of socialist education". Private higher education is the important component of higher education system, undertake the task of the part of the popularization of higher education, provide more higher education opportunities for more people, and cultivate a large number of talents for the society. However, the government and the public lack of understanding of private higher education improved.

The policies and regulations of private higher education need to be updated and

The Regulations on Social Forces of Running a School is the first regulation in the field of private education in China, which is issued in October 1997, but private higher education in China recovered from the late 1970s and early 1980s, policies and regulations lag behind the practice of nearly 20 years. In 2002, the state issued the Private Education Promotion Law of The People's Republic of China, more than 10 years past from that time. The above regulations provide legal protection for the development of private education, but the rules is not specific, interoperability is not strong.

Because of the lagging behind of policies and regulations, private colleges and public colleges' status are not equal, could not in a relatively fair sense to recruit students, teaching and managing; Management personnel and teaching staff are not involved into national and local government support and development system; There are many restrictions in the names, professional curriculum, title evaluation, project application of private colleges.

The development autonomy of private higher education should be strengthened.

Government has too much administrative intervention to private colleges, in the field such as access to education, professional settings, recruit students number, charge standard management, the management is too rigid, not fully consider the plight and actual situation of private colleges. Take the government's enrollment strict control for example, recruit students is to ensure the revenues, maintain normal operation and the basic guarantee of the development of school, but the current enrollment is a kind of planning manner.

All kinds of unfavorable external environments have closed relationships with the internal factors such as funds, treatment, teaching conditions and etc. For the improvement of external environment, private colleges often can't control, only through industry associations and other non-governmental organizations to appeal and advice, the change of external environment needs a long process. Therefore, analyze from the internal influence factors and put forward development countermeasure and the suggestion from the perspective of strategy is a better choice. The internal factors which restrict the development of the private colleges in China are two aspects mainly involved funds and personnel.

\section{Internal Factors Analysis}

Funds

At present, main source of financial support for most of private colleges is the tuition and fees, the education funding sources are simple. According to a survey [19], In 38 sample private colleges, number of the colleges whose fees accounted for $100 \%$ is 14,9 colleges accounted for $90 \%, 9$ colleges accounted for $80 \%$, and 4 colleges accounted for $70 \% 1$ college accounted for $60 \%$, only 1 accounted for below $40 \%$. 
The Ministry of Education and local government supply different level of funding for public colleges, besides tuition and fees income, government funding is also important for public colleges. Take the "project 985" colleges for example, from 1999,"985 project" funding has been allocated to three phases, the issuing allocated quota from 300 million Yuan to 1.8 billion Yuan, Beijing university won 7.6 billion Yuan from the "985 project" funding in 15 years. For private college's weak level of funding, many colleges have to choose the way to charge high fees in order to maintain operation. According to a study of a scholar Wu Daguang, in 2000, the tuition of South China Industrial and Commercial College, Zhejiang University City College, Sanjiang College are 10000-15000 Yuan/year; In 2005, Beijing Geely College common professional fees is 8000-8500 Yuan /year, ordinary professional fee of private colleges in Shaanxi province is 5500-5500 Yuan/year. Tuition and fees of private colleges is generally higher than public colleges, high tuition has the direct impact to recruitment; second, the shortage of funds of private colleges caused the poor teaching conditions, especially the instruments and equipment, books in the library, directly affect the teaching quality. Funding difficulties seriously affect the healthy development of private colleges.

Personnel

The personnel factors affecting the development of private colleges are mainly two aspects: one is the teacher, the other one is the student.

Full-time and part-time faculty co-exist, the structure is not reasonable.

Good teachers are a necessary condition for development of a college. But in China's private colleges, full-time teacher ratio is very low; the majority is the part-time teachers. Look from the age structure, most of the private colleges teachers are "dumbbell" structure, most of them are new graduates and retired teachers, less middle-aged teachers [20], Look from the education structure, the majority of them only got the undergraduate degree, master's and doctoral graduate students are in the minority. Investigation of several private colleges in Beijing, retired teachers account for more than $70 \%$, part-time teachers account for nearly $30 \%$. In the northeast, retired and part-time personnel account for $90 \%$ [21].Private colleges teachers' structure is unreasonable and unstable, affects the improvement of school teaching quality.

Students' quality is not ideal.

After a period of strong demand in the 1990s, private higher education in China began to have the problem of insufficient demand [22], that is the problem of insufficient enrollment. Especially after the 1999 enrollment expansion of public colleges and independent colleges, coupled with the influence of traditional ideas, people have a special liking to public colleges. Some of the private colleges' individual demand decrease.

In the situation of lack of students, in order to compete for a limited number of students, fierce competition appeared between private colleges, most of the private colleges drop the screening mechanism, students learning ability is uneven, the study enthusiasm is not high.

\section{SUGGESTIONS AND COUNTERMEASURE}

Design Strategy under the Guidance of National Policy; take the Initiative to Choose Development Pattern in the Future.

National Medium and Long-term Program for Education Reform and Development pointed out the strategic goal of education development in China: by 2020, realize modernization of education, form a learning society, the country would be rich in human resource.

There is no doubt that policy is one of the most important resources in future development of Chinese private higher education. Review the history of Chinese higher education, if there is no government policies and promotion, the development of Chinese private higher education is hard to be today's scale. Although policies often lag behind the development of practice, they had played a huge role in promoting the development of 
Chinese private higher education, so is the future. The golden period of private higher education development in China is short, the basis of private college development is still very weak, they need constant state policies and stable policy environment to accumulate operating conditions and resources, and explore the private higher education educational pattern with Chinese characteristics.

So, on one hand, private colleges should take advantage of such as association and other organizations to call for and suggest, strive for policies and resources beneficial to the development of private higher education, design strategy actively under the policy guidance, form their own educational philosophy and style.

On the other hand, the development of private colleges should make clear the future pattern. Many of the higher education researchers put forward insights of the future development of private higher education patterns in China. A famous higher education scholar Pan Maoyuan thought to promote the sustained and healthy development of private higher education, we should follow the multivariate management policy, allow a third pattern of private colleges, support for its development. It's the "third way" of the development of the private higher education.

Zha Minghui put forward the future development pattern of Chinese private higher education --- Social Enterprise Development Pattern. Emphasize the enterprise means to raise funds. Private higher education's social enterprise development pattern is to make private colleges as social enterprises, in order to meet some students' demand of the higher education. Currently, the traditional non-profit development pattern of private higher education in US has turned into social enterprise development pattern actually [23].

Private higher education classification management policies should supply more paths for the development of private higher education, and support the investment in running schools which could obtain reasonable return. Support the "third way" such as social enterprise pattern to develop the private higher education actively. This is the inevitable requirement of development of private higher education in China at present stage [24].

Strive For Government Support and Subsidies

For external support, private colleges should strive for the substantial support of the government actively. Private colleges could organize association of private education, through repeated calling for and advice, trying to let the government realize the role and contribution of the private colleges. On the basis of existing policies, develop more substantial, more conducive policies for the development of private college.

Furthermore, private colleges should strive for more specific policy and financial support from the government. At present, there is a large gap between private and public colleges in enjoying the preferential policies. Government should give more preferential policies in the land, tax, enrollment, financial aid, loans, books and equipment, etc. In fact, the government provides financial aid for private colleges is a worldwide phenomenon, such as the United States, Australia, Japan, etc. In US, its private college funding sources is diversified, the proportion of federal government funding is relatively large, even more than public colleges, above 11\% since 1994 [25].

Internal Promotion

Characteristics and influence factors of the private higher education have inherent logic relationship. The difficulty of private colleges' funds due to a limited number of students; difficulty for admissions is from poor social reputation; poor social reputation is the result of internal teaching quality and level of employment. So, the internal ascension is the fundamental countermeasures.

Guide the whole society to invest private higher education.

Higher education funding has the following five ways: one is the state funding; the second is the social donation; the third is the social investment; the fourth is the tuition; the fifth is loan. To analyze the ways, increase of higher education investment from state is not realistic; for lack of a progressive tax arrangements, we cannot arouse the 
enthusiasm of people donated; there is no space for rising tuition; Loan has amounted to hundreds of billions of public colleges, and many private colleges also has a large number of loans; Therefore, encouraging and advocate the social investment in education strongly is a good way [26].

Raise the level of faculty.

In short term, the situation part-time teachers being the majority could not be changed, so in the short-term, we need to develop and implement strictly part-time teachers hiring procedure, employed good teachers; strengthen the management after employed, improve examination system. At the same time, part-time teachers should be given full autonomy in teaching.

In the long run, to enlarge the recruitment, recruit outstanding doctor and master graduate students, increasing proportion of full-time teachers. For full-time teachers, pay more attention to the training work, establish and perfect the title evaluation system; Provide regular education and training opportunities.

Pay special attention to the recruitment, cultivating and employment, improve students' quality.

Improvement of private colleges' admissions standards would greatly influence education funds income, but from a strategic analysis, to enhance social reputation, it is necessary to gradually increase the admissions standards, appropriate sacrifice short-term profits. At present, the situation private colleges students academic performance being lower than public colleges students could not be changed in the short term, but private colleges can work in the process of the cultivation of the students, strengthen the teaching and daily management, promote students' learning ability and comprehensive quality, the quality of private college graduates and career development is vital for the reputation of the school.

The main factors of private college development has influence each other, it is a system. Therefore, private colleges in China have to adapt and improve the external environment, make efforts to solve the internal problems. With the improvement of the policies and regulations, government financial support, the improvement of teachers' quality, teaching quality and service level of private colleges, highlighting the nongovernment college characteristics, and social reputation will be improve gradually, recruiting problems will be readily solved, private colleges will enter a healthy, rapid and stable development stage.

\section{References}

[1] L. L. Carstensen, D. M. Isaacowitz and S. T. Charles, "Taking time seriously: A theory of socioemotional selectivity", American Psychology, vol. 54, (1999), pp. 165-181.

[2] Y. Liu, "Present situation, problems and development tendency of private higher education in China", Education Research, vol. 9, (2004), pp. 71-76.

[3] J. Yan, "The main problems and countermeasures research of private colleges", Shandong Normal University, vol. 20, (2008).

[4] L. Liu, "The present situation and sustainable development countermeasures of private colleges in Shandong province", China's school education, vol. 12, (2011).

[5] Y. Lv, "The present development situation and countermeasure analysis of private colleges in Beijing", China's education academic essays in economics in, vol. 12, (2010).

[6] S. Yang, "The present situation and countermeasure research of ideological and political quality in private colleges", Southwest University, (2012).

[7] H. Chen, "The student management present situation and countermeasure research of private colleges in Jiangxi province", Jiangxi Normal University, (2008).

[8] C. Zhao, "The scientific research present situation and countermeasure research of private colleges", Hunan Normal University, (2008).

[9] J. Mao, "The analysis and suggestion of internal factors which restrict the development of the private colleges in China", Vocational and Technical Education, vol. 29, no. 7, (2007).

[10] "National Education Statistical Bulletin in 2012", (n.d.), (2013), from http://www.moe.gov.cn/publicfiles/business/htmlfiles/moe/moe_1485/201308/xxgk_155798.html. 
[11] M. Pan, "The development of private higher education needs more paths", Higher Education Weekly, (2012), pp. 1-3.

[12] Y. Qian, "The classification controversy of private colleges", Oriental Outlook, vol. 40/41, (2011), pp. $42-47$.

[13] M. Cha, "The development pattern research of private higher education in China", Nankai University, (2010).

[14] J. Liu, Translate. "Organization for economic cooperation and development: Social enterprise", Social Sciences Academic Press, (2004)

[15] Y. Ke, "The equilibrium of supply and demand of private higher education in China", Private Education Research, vol. 1, no. 53, (2005).

[16] "National Education Statistical Bulletin in 1999", (n.d.), 2000 National Education Statistical Bulletin in 2003. (n.d.), $\quad$ (2004), from http://www.moe.gov.cn/publicfiles/business/htmlfiles/moe/moe_1485/201308/xxgk_155798.html.

[17] C. Lu, "The review and preview of China's private higher education", Exploring Education Development, vol. 3B, (2007), pp. 1-3.

[18] J. Mao, "Research of the plight of private higher education development in China", Education and Vocation, vol. 4, (2006).

[19] D. Wu, "The private higher education development situation analysis in China (1)", Exploring Education Development, vol. 7, (2001), pp. 23-28.

[20] Y. Xia, Where are teachers of private colleges from. China Education Daily, (2001) April 10, pp. 10.

[21] M. Zha, "The necessity of development pattern transformation of private higher education: from marketization to social enterprise", Hubei Social Sciences, vol. 1, (2014), pp. 168-171.

\section{Author}

Yong Duan, is a Ph.D. student in School of management, Donghua University. His research direction is education of private college. 
International Journal of Hybrid Information Technology Vol.8, No.12 (2015) 